\title{
PENGEMBANGAN BAHAN AJAR PAI POKOK BAHASAN ASPEK AKIDAH BERBASIS PEMBELAJARAN METAFORA DALAM MENINGKATKAN PEMAHAMAN KONSEP SISWA SMPN 17 KOTA BENGKULU
}

\author{
AlFauzan Amin \\ IAIN Bengkulu \\ farhan@gmail.com
}

\begin{abstract}
The he research subjects for product trials that were developed in the study were students of SMPN 17 Bengkulu City in 2017. The small group trial subjects were 10 students who were selected by purposive sampling. Large group trial subjects 65 students. The research development steps are: (1) potential and problems, (2) data collection, (3) Product Design, (4) design validation, (5) design revision, (6) product trial, (7) product revision, (8) trials of use, (9) product revisions, (10) Mass production). Based on the research it can be concluded that teaching materials are developed based on needs analysis. The results of the development in the form of a draft were then tested for validation, tested for practicality and effectiveness. The results of validation of metapora-based PAI teaching materials for students in the form of printed teaching materials (books) with the metapora approach by experts and practitioners have fulfilled the eligibility component as valid teaching materials. The process of learning activities with metapora-based PAI teaching materials for students has fulfilled the eligibility component as material practical teaching. Student responses and the final results of learning activities with metapora-based PAI teaching materials for students have fulfilled the feasibility component as practical teaching materials. Student responses and the final results of learning activities with metapora-based PAI teaching materials have met the eligibility component as an effective teaching material, with proven metapora teaching materials proven to have been able to improve student learning outcomes.
\end{abstract}

Keywords: MUI, Halal Product, Islamic Law, Halal Certification

\begin{abstract}
Abstrak. Subjek penelitian untuk uji coba produk yang dikembangkan dalam penelitian adalah siswa SMPN 17 Kota Bengkulu Tahun 2017. Subjek uji coba kelompok kecil adalah 10 orang siswa yang dipilih secara purposive sampling. Subjek uji coba kelompok besar 65 orang siswa. Adapun langkah-langkah penelitian pengembangan adalah: (1) potensi dan masalah,(2) pengumpulan data, (3) Desain Produk, (4) validasi desain, (5) revisi desain, (6) uji coba produk, (7) revisiproduk, (8) ujicoba pemakaian,(9) revisi produk, (10) Produksi massal). Berdasarakan penelitian dapat disimpulkan bahwa bahan ajar dikembangkan berdasarkan analisis kebutuhan. Hasil pengembangan berupa draft kemudian diuji validasi, diuji kepraktisan dan keefektifan. Hasil validasi bahan ajar
\end{abstract}


PAI berbasis metapora bagi siswa berupa bahan ajar cetak (buku) dengan pendekatan metapora oleh abli dan praktisi telah memenuhi komponen kelayakan sebagai bahan ajar yang valid.Proses kegiatan pembelajaran dengan bahan ajar PAI berbasis metapora bagi siswa telah memenuhi komponen kelayakan sebagai bahan ajar yang praktis. Respon siswa dan hasil akhir kegiatan pembelajaran dengan bahan ajar PAI berbasis metapora bagi siswa telah memenuhi komponen kelayakan sebagai bahan ajar yang praktis. Respon siswa dan hasil akhir kegiatan pembelajaran dengan bahan ajar PAI berbasis metapora telah memenuhi komponen kelayakan sebagai bahan ajar yang efektif, dengan dibuktikan bahan ajar metapora ini terbukti telah mampu meningkatkan hasil belajar siswa.

Kata Kunci: Bahan ajar, Metafora, Konsep Abstrak

\section{Pendahuluan}

Pentingnya pendidikan Agama Islam yang berkualitas semakin disadari, sebab terciptanya kualitas manusia yang maju dan mandiri hanya dapat diwujudkan, jika pendidikan masyarakat berhasil ditingkatkan. Namun mutu pendidikan masih tertinggal dibandingkan dengan negara-negara maju lainya ${ }^{1}$. Sedangkan keadaan dalam negeri sendiri jika dilihat tingkat provinsi dari segi lama sekolah terlihat setiap daerah memiliki beragam masa sekolah. Berdasarkan target yang diusulkan UNDP maka rata-rata pendidikan penduduk Indonesia relatif tertinggal $^{2}$. Namun demikian ada pendidikan aspek pembentukan keimanan, ketaqwaan dan ahlaq mulia serta sikap toleransi dalam kehidupan menjadi prioritas dalam pendidikan bangsa.

Pendidikan Agama Islam di dalamnya memuat aspek bahasan yang bervariasi. Aspek aqidah adalah salah satu pokok bahasan penting. Oleh karena itulah peningkatan pendidikan agama, terutama pokok bahasan Aqidah adalah hal penting yang patut memperoleh perhatian. Karena Aqidah adalah pangkal pembinaan pendidikan moral bangsa. Namun pada tataran realita masih terdapat problem utamanya dalam pembelajaran di tingkat Sekolah Menengah Pertama. Hal ini dikarenakan pokok bahasan Aqidah tergolong materi ajaran agama yang bersifat abstrak dan memerlukan pemikiran mendalam untuk mencerna sehingga dapat dipahami siswa. Realita ini diakui beberapa guru agama, berdasarkan penelitian pendahuluan bahwa materi aspek Aqidah tergolong materi yang "gampang-gampah susah" diajarkan, karena sifatnya yang

${ }^{1}$ Tahun 2011, HDI menempatkan Indonesia berada pada urutan ke-121 medium buman depelopment dari 186 negara. Human Development Report 2013, The Rise of the South Human progress in a Diverse World taBE3 Inequality-adjusted, Human Development Index, Published for the United Nations Development Programme (UNDP) 1 UN Plaza, New York, NY 10017, USA, h. 153.

${ }^{2}$ Berdasarkan tingkat propinsi peringkat, Bengkulu urutan ke 12 pada tahun 2006 dan ke 13 tahun 2007 rata-rata lama sekolah 8 tahun, IPM 2006-2007, h. 26. LihatBadanPusatStatistik, Indeks Pembangunan Manusia (IPM) 2006 - 2007, Jakarta - Indonesia, Katalog BPS: 4102002, h. 26-28. 
abstrak. Demikian pula siswa merasa sulit belajar menguasai pemahaman aspek ajaran aqidah khususnya yang menyangkut keimanan - misalnya iman kepada Malaikat Allah SWT.

Materi iman kepada malaikat Allah, secara penguasaan pemahaman tingkat rendah sekedar menghafal dalil, menyebut nama malaikat, tugas-tugas malaikat memang mudah dikuasai. Tetapi untuk tingkat penguasaan pemahaman siswa yang harus dikuasai anak sekolah menengah pertama tentu sudah harus tidak sekedar seperti pada tingkat sekolah rendah. Hal inilah yang dirasakan sulit karena siswa sekolah menengah pertama belajar agama hanya dalam waktu terbatas. Sementara penguasaan pemahaman agama harus meningkat. Mengatasi kesulitan pembelajaran pokok bahasan Aqidah terutama materi aspek iman kepada malaikat Allah perlu pendekatan yang tepat. Salah satunya sesuai dengan kajian teori konsep pendekatan pembelajaran adalah menggunakan metapora.

Pendekatan metapora sering digunakan dalam proses pembelajaran materi kesustraan. Pendekatan ini dianggap sesuai karena sifat materi yang didalam memuat konsep-konsep pemahaman yang abstrak. Sama halnya dengan materi agama utamnaya pokok bahasan Aqidah sub materi Iman kepada malaikat Allah. Namun pada penelitian kali ini akan lebih kongrit dalam menawarkan solusi kesulitan pembelajaran ini dengan memproduksi hasil penelitian dalam bentuk bahan ajar praktis. Bahan ajar yang menawarkan yang akan dihasilkan dalam kegiatan penelitian dan pengembangan ini adalah bahan ajar Pendidikan Agama Islam pokok Bahasan Aqidah sub materi Iman kepada Malaikat Allah SWT.

\section{Hasil dan Pembahasan}

Pembelajaran PAI aspek Aqidah adalah yang berkenaan dengan materi abstrak. Materi aqidah didalamnya membicarakan keimanan. Karena materi yang abstrak maka perlu upaya agar pemahaman konsep tersebut mudah dipahami siswa. Aspek Aqidah dalam hal ini dibatasi pada Iman kepada Malaikat. Materi tergolong sulit karena sifatnya yang abstrak malaikat adalah mahluk Allah yang mulya diciptakan dari cahaya dan sifatnya ghaib. Namun bukan berarti tidak ada melainkan ada. Materi ini diajarkan pada kelas VII siswa Sekolah Menengah Pertama. Hal ini berdasarkan silabus mata pelajaran PAI untuk siswa Sekolah Menengah Pertama kelas VII. Dalam upaya mempermudah penyampaian materi konsep abstrak ini diantaranya sebagaimana petunjuk Alqur'an adalah dengan metafora atau amtsal.

1. Hakekat Metafora

Metafora dalam bahasa Arab disebut Amtsal yang berarti perumpamaan.Amtsal adalah bentuk jamak dari kata matsal (perumpamaan) atau Mitsil (serupa) atau matsil, sama halnya dengan kata syabah atau syabih. Karena itu dalam ilmu balaghah, pembahasan yang sama ini lebih dikenal dengan istilah tasybih, bukan amtsal. Dalam pengertian bahasa (etimologi), amtsal menurut Ibn Al-Farits adalah persamaan dan perbandingan sesuatu 
dengan sesuatu yang lain. ${ }^{3}$ Atau menurut Al-Ashfahami, amtsal berasal dari kata al-mutsul, yakni al-intishab (asal, bagian). Matsal berarti mengungkapkan perumpamaan. ${ }^{4}$

Amtsal menurut pengertian istilah (terminology) dirumuskan para ulama dengan redaksi yang berbeda-beda. Menurut Rasyid Ridha; Amtsal adalah kalimat yang digunakan untuk member kesan dan menggerakkan hati nurani. Bila di dengar terus, pengaruhnya akan menyentuh lubuk hati yang paling dalam. ${ }^{5}$ Menurut Ibn Al-Qayyim; Amtsal yaitu menyerupakan sesuatu dengan sesuatu yang lain dalam hukumnya, mendekatkan sesuatu yang abstrak dengan sesuatu yang kongkrit, atau salah satu dari keduanya dengan yang alinnya. ${ }^{6}$ Menurut Muhammad Bakar Ismail; Amtsal Al-Qur'an adalah mengumpamakan sesuat dengan sesuatu yang lain, baik dengan jalan isti'arah, kinayah atau tasybih.

Berdasarkan pengertian diatas, baik secara bahasa maupun istilah, dapat disimpulkan bahwa amtsal Al-Qur'an adalah menampilkan sesuatu yang hanya ada dalam pikiran (abstrak) dengan deskripsi sesuatu yang dapat di indera (konkrit), melalui pengungkapan yang indah dan mempesona, baik dengan jalan tasybih, isyti'arah, kinayah atau mursal .

Dilihat dari segi istilah, amtsal dikenal sebagai salah satu aspek ilmu sastra arab. Pengertian amtsal dalam Al Qur'an lebih tepat digunakan untuk mengacu pada kesan dan sentuhan perasaan terhadap apa yang dikandungnya, tanpa mempersoalkan ada atau tidak adanya kisah yang berhubungan dengan amtsal itu. Kendatipun demikian amtsal yang berangkat dari kisah nyata, banyak disebutkan dalam Al Qur'an, dan ini lebih tepat dinamakan dengan tamtsil, karena disusun menurut bentuk tamtsil, bukan dalam bentuk berita.

2. Macam-macam Perumpamaan dalam Al Qur'an

Menurut Al Qaththan, amtsal Al Qur'an dapat dibagi menjadi 3 bagian, yaitu:

a. Amtsal Musharrahah

Yang dimaksud dengan Amtsal Musharrahah adalah Amtsal yang jelas, yakni yang jelas menggunakan kata-kata perumpamaan atau kata yang menunjukkan penyerupaan (tasybih), contohnya dalam QS. Al Baqarah: 17-20;

Artinya: "Perumpamaan mereka adalah seperti orang yang menyalakan api, maka setelah api itu memerangi sekelilingnya, Allah menggilanhkan cahaya (yang menyinari) mereka, dan membiarkan mereka dalam kegelapan, tidak dapat melihat. Mereka, tuli, bisu, dan buta, maka tidaklah mereka akan kembali (ke jalan yang benar), atau seperti (orang-orang yang ditimpa) hujan

\footnotetext{
${ }^{3}$ Muhammad Bakar Isma'il, Dirasat fi Ulum Al Qur'an, (Dar Al Manar, Kairo: 1991), b. 337.

${ }^{4}$ Ar Ragib Al Isfahani, Mu'jam Mufradat Alfaz̧ Al Qur'an, (Dar Al Fiker, Beirut: t.t)., h. 462.

${ }^{5}$ Muhammad Rasyid Ridha, Tafsir Al Manar, Jilid I, (Dar Al Fiker, Beirut: t.t)., h. 236.

${ }^{6}$ Manna Al Qaththan, Mababits fi Ulum Al Quran, (Mansyurat Al Hasyr Al Hadits, 1973), h. 283.
} 
lebat dari langit disertai gelap gulita, guruh, dan kilat; mereka menyumbat telinganya dengan anak jarinya, karena (mendengar suara) petir, sebab takut akan mati. Dan Allah meliputi orang-orang yang kafir. Hamper-hampir kilat menyambar penglihatan mereka. Setiap kilat itu menyinari mereka, mereka berjalan di bawah sinar itu, dan bila gelap menimpa mereka, mereka berhenti. Jikalau Allah menghendaki, niscaya Dia melenyapkan pendengaran dan penglihatan mereka. Sesungguhnya Allah berkuasa atas segala sesuatu."

Pada contoh itu terlihat jelas kata-kata yang menunjukkan perumpamaan dan penyerupaan, yaitu matsaluhun dan aw kasyayyibin. Contoh di atas juga memperlihatkan dua perumpamaan bagi orang munafik. Pertama, seperti orang yang menyalakan api (katsal ladzi istauqad nar) karena di dalam api terdapat unsure cahaya. Kedua, seperti orang-orang yang ditimpa hujan dari langit (au ka shayyibin min as-sama'i), karena di dalamnya terkandung unsure kehidupan. Allah telah menurunkan wahyu dari langit untuk menerangi dan menghidupkan hati hamba-Nya.

b. Amtsal Kaminah

Yang di maksud dengan amtsal kaminah adalah amtsal yang tidak menyebutkn dengan jelas kata-kata yang menunjukkan perumpamaan, tetapi kalimat itu mengandung pengertian yang mempesona, sebagaimana yang terkandung di dalam ungkapan-ungkapan singkat (ijaz).

c. Amtsal Mursalah

Yang dimaksud dengan amtsal mursalah adalah kalimat-kalimat Al-Qur'an yang disebut secara lepas tanpa di tegaskan redaksi penyerupaan, tapi dapat di gunakan untuk penyerupaan, contohnya berikut ini.

Firman Allah surat Yusuf: 51,

Artinya: "berkata istri Al-Aziz, "sekarang jelaslah kebenaran itu, akulah yang menggodanya untuk menundukkan dirinya (kepadaku), dan sesungguhnya dia termasuk orang yang benar." 7

Dalam konteks lain macam-macam perumpamaan yang terdapat di dalam Al-Qur'an, yaitu tertera juga di QS An-Nur: 35

Artinya: "Allah merupakan cahaya langit dan bumi. Perumpamaan cahaya Allah adalah seperti sebuah lubang yang tidak tembus. Di dalamnya ada pelita besar. Pelita itu di dalam kaca. Kaca itu seakan-akan bintang yang seperti mutiara, yang di nyalakan dengan minyak dari pohon yang di berkati, yitu pohon zaitun yang tumbuh tidak di sebelah timur dan tidak pula di sebelah barat, yang minyaknya saja nyaris menerangi walaupun tidak di sentuh api. Cahaya di atas cahaya. Allah membimbing kepada cahaya-Nya siapa yang di kehendaki. Dan Allah membuat perumpamaan-perumpamaan bagi manusia. dan Allah maha mengetahui segala sesuatu."

${ }^{7}$ RosihonAnwar, Ilmu Tafsir, (CV Pustaka Setia, Bandung: 2000), h. 93-105. 
Firman Allah, "Allah merupakan cahaya langit dan bumi. "Ali Bin Abi Thalhah meriwayatkan dari Ibn Abbas, dia berkata: "Allah menunjukkan penduduk langit dan bumi." Ibn Jarir meriwayatkan dari Anas Bin Malik, dia berkata: "Allah berfirman, 'cahaya-Ku adalah petunjuk'. Penafsiran ini di lihat oleh Ibn Jarir. "perumpamaan cahaya Allah", yakni perumpamaan hidayah-Nya dalam diri mukmin yang telah di masukkan kedalam hatinya keimanan dan AlQur'an. Ubay Bin Ka'ab membaca penggalan ini dengan: matsalu nuri man amana bihi (perumpamaan orang yang beriman kepada-Nya). Dia adalah orang mukmin, Allah telah menempatkan keimanan dan Al-Qur'an di dalam kalbunya. Demikian pula diriwayatkan oleh Said Bin Jubeir dan Qa'is Bin Sa'ad bahwa Ibn Abbas membaca penggalan itu dengan: matsalu nuri man amana bihi. Ulama lain membaca dengan: Allahu munawwirusasamawatiwal-ardha. Dan AdhDhahak membaca dengan: Allah nawwaras-samawati wal-ardha.

Firman Allah Ta'ala, "perumpamaan cahaya-Nya". Hati orang mukmin yang dalamnya tedapat hidayah dari Allah dan Al-Qur'an diserupakan dengan pelita yang terbuat dari kaca bening seperti mutiara. Hidayah yang di peroleh orang mukmin dari Al-Qur'an dan syari'at di serupakan dengan minyak yang berkualitas, murni, bersinar, dan tidak ada sedikitpun kotoran di dalamnya.

Firman Allah, "dan Allah membuat perumpamaan-perumpamaan bagi manusia. dan Allah maha mengetahui segala sesuatu”. Setelah Allah menceritakan perumpamaan cahaya hidayah-Nya yang ada dalam kalbu seorang mukmin, maka Dia mengakhirinya dengan: "Dan Allah membuat perumpamaan-perumpamaan bagi manusia. dan Allah maha mengetahui segala sesuatu". Dia Maha Mengetahui siapa yang berhak menerima hidayah dan siapa yang berhak menerima kesesatan. ${ }^{8}$

3. Manfaat dan tujuan metode perumpamaan atau metafora dalam Al Qur'an

Manna Al Qaththan menjelaskan bahwa diantara manfaat perumpamaan Al Qur'an adalah; (a) Menampilkan sesuatu yang abstrak (yang hanya ada dalam pikiran) ke dalam sesuatu yang konkret-material yang dapat diindera manusia. Dengan cara ini, akal dapat menerima pesan yang disampaikan oleh perumpamaan itu. Makna yang abstrak masih membuat hati ragu, kecuali bila telah ditransfer terlebih dahulu ke dalam makna yang konkret. Contoh Allah membuat perumpamaan terhadap sesuatu yang diinfakkan secara riya'. Pekerjaan infak itu tidak menghasilkan balasan pahala sedikitpun. (b) Menyingkap makna yang sebenarnya dan memperlihatkan hal-hal gaib melalui paparan yang nyata, seperti disebutkan dalam firman Allah dalam surat $\mathrm{Al}$ Baqarah: 275. (c) Menghimpun arti yang indah dalam ungkapan yang singkat sebagaimana terlihat dalam amtsal kaminah dan amtsal mursalah. (d) Membuat si pelaku amtsal menjadi senang dan bersemangat, seperti disebutkan dalam firman Allah surah Al Baqarah: 261. (e) Menjauhkan seseorang dari sesuatu yang tidak disenangi seperti disebutkan dalam firman Allah surah Al Hujurat:

${ }^{8}$ Muhammad Nasib ar-Rifa'i, Taisiru al-Aliyyul Qadir li Ikbtishari Tafsir Ibn Katsir Jilid 2, (Maktabah Ma’rif Riyadh, Jakarta: 1989), h. 498-500. 
12. (f) Memberikan pujian pada pelaku, seperti disebutkan dalam Al Qur'an surah Al Fath: 29. (g) Memperlihatkan bahwa yang dijadikan perumpaan memiliki sifat yang tidak disenangi manusia, seperti disebutkan dalam firman Allah Surah Al A'raf: 175-176. (h) Pesan yang disampaikan melalui amtsal lebih mengena di hati lebih mantap dalam menyampaikan nasehat; dan lebih kuat pengaruhnya Allah sendiri banyak menggunakan amtsal di dalam Al Qur'an dengan tujuan memberikan peringat dan nasehat.Ilmu Al Qur'an yang paling agung, menurut Al Mawardi, adalah amtsal-nya, Asy Syafi'i mengharuskan seseorang mujtahid mengetahui ilmu-ilmu Al Qur'an, termasuk didalamnya adalah amtsal-nya.

Dalam membuat perumpamaan disyaratkan ucapan-ucapan itu sebagai penjelas, atau tidak semata-mata ucapan yang tidak ada manfaatnya. Sedangkan tujuan dari metode perumpamaan $\mathrm{Al}$ Qur'an adalah:

Menurut Najib (2002: 125) dalam Al-Qur'an ditemukan tujuan perumpamaan yang dapat diringkas menjadi enam tujuan, yaitu:(a) Perumpamaan dapat mendekatkan gambaran yang diumpamakan dalam pikiran pendengar.(b) Merasa puas dengan satu gagasan tertentu, sehingga kepuasan itu menjadi satu argumen yang kokoh lewat gambaran yang mirip.(c) Memberikan motif dengan cara memperindah dan menakut-nakuti(d) Memiliki hasrat dan keinginan, sehingga setelah hasrat atau keinginan lahir, maka orang akan memiliki ketetapan hati untutk menerima apa yang disarankan. (e) Untuk memuji atau mencela juga untuk mengagungkan atau menghinakan. (f) Mengasah otak dan menggerakkan potensi pemikiran atau timbul kesadaran untuk merenung dan tafakur. ${ }^{9}$

Metode perumpamaan menurut An-Nahlawi mempunyai tujuan pedagogis diantaranya sebagai berikut: (a) Mendekatkan makna pada pemahaman. (b) Merangsang kesan dan pesan yang berkaitan dengan makna yang tersirat dalam perumpamaantersebut yang menggugah atau menumbuhkan pelbgai perasaan ketuhanan. (c) Mendidik akal supaya berpikir logis dan menggunakan qiyas yang logis dan sehat. (d) Perumpamaan merupakan motif yang mengerakkan perasaan menghidupkan naluri, yang selanjutnya menggugah kehendak dan mendorong seseorang untuk melakukan amal yang baik dan menjauhi segala kemungkinan ${ }^{10}$

Penggunaan metafora dalam pembelajaran mempunyai peranan yang sangat penting, yaitu kemampuan menciptakan minat dan meningkatkan motivasi belajar para siswa. Metafora yang dimaksud dalam tulisan ini adalah memaparkan cerita tentang hakikat kesuksesan, perumpamaan-perumpamaan mengenai suatu bentuk kehidupan yang mereka alami sekarang dan yang akan mereka hadapi kelak, simulasi, ataupun kisah-kisah berbagai orang sukses yang berkaitan dengan materi, serta legenda-legenda lainnya. Diharapkan nantinya,

\footnotetext{
${ }^{9}$ Abdul Majid, Perencanaan embelajaran: mengembangkan Standar Kompetensi Guru, (PT Remaj Rosda Karya, Bandung: 2009), h. 144-147.

${ }^{10}$ Heri Gunawan, Tafsir Tarbawi, (PT Remaja Rosdakarya, Bandung: 2014), h. 64-65.
} 
setelah pembelajaran agama selesai, setiap siswa sebagai pembelajar memiliki wawasan lebih tentang kehidupan nyata yang akan mereka songsong, sehingga motivasi mereka untuk lebih sungguh-sungguh belajar dapat ditingkatkan.

Tujuan utama penggunaan metafora dalam pembelajaran agama adalah untuk meningkatkan minat dan motivasi siswa dalam belajar, bukan hanya belajar agama tetapi belajar nilai-nilai kehidupan. Metafora menggugah motivasi siswa untuk belajar agama, memberdayakan potensi mereka untuk menjawab tantangan dalam simulasi agama, dan yang paling penting menjelajahi nilai-nilai kehidupan yang menginspirasi mereka untuk melakukan upaya terbaik dalam hidupnya.

Banyak metafora yang dapat digunakan atau disampaikan dalam setiap pembelajaran, diantaranya: (1) bercerita dengan menggunakan perumpamaan untuk menumbuhkan kesadaran betapa pentingnya pembelajaran tersebut, (2) bercerita dengan perumpamaan, pengaitan materi terhadap hal-hal nyata untuk lebih memudahkan pemahamannya, (3) memberikan penjelasan bagaimana cara-cara tepat dan cepat dalam mempelajari materi pelajaran, (4) menyajikan paparan bahwa orang belajar harus siap keluar dari "zona nyaman", (5) mengisahkan tentang beberapa tokoh yang ada kaitannya dengan kesuksesan dalam belajar terkhusus materi yang dipelajarinya, dan (6) memberikan beberapa nasihat dan tips untuk meraih keberhasilan dalam belajar agama. Demikianlah bentuk-bentuk metafora yang tertuang dalam pembelajaran.

4. Bahan Ajar PAI Berbasis Metafora

Salah satu tugas Guru Pendidikan Agama Islam (GPAI) adalah mentransinternalisasikan nilai-nilai Islam kepada peserta didik melalui interaksi dalam proses pembelajaran yang dilakukannya. Keberhasilan guru dalam kegiatan belajar mengajar sangat tergantung dengan pendekatan, model dan metode atau teknik serta perangkat pembelajran lainya yang ditetapkan. Kegagalan pembelajaran seringkali karena kurang tepatnya guru dalam mendesain pembelajaran. Untuk materi agama terlebih aspek aqidah (Iman kepada Malaikat) sebagai modal dasar yang harus dibekalkan kepada siswa, masih terdapat guru yang menganggap materi ini mudah diajarkan. Salah satu syarat yang harus dipenuhi agar pembelajaran agama khususnya aspek Aqidah sesuai dengan tujuan, yaitu untuk mencapai kemampuan kreatif, pemilihan model pembelajaran harus diperhatikan dengan baik. Mengingat masih adanya kesulitan siswa Sekolah Menengah dalam memahami konsep abstrak materi agama aspek aqidah, maka perlu mendesain model pembelajaran yang betul-betul dapat menolong baik siswa maupun guru dalam proses pembelajaran. Suatu pendekatan baru yang menarik dalam mengembangkan kreativitas telah dirancang oleh Gordon dengan unsur metafora sangat relevan digunakan dalam pembelajaran pemahaman konsep abstrak materi agama.

Seiring dengan masa perkembangan anak usia awal remaja (siswa SMP) dengan karakternya yang sudah mulai berkembang yaitu cara berfikirnya yang mulai kritis, dan tentunya tuntutan zaman sekarang yang sudah maju, harus mendapat respon secara positif. Salah satu respon adalah berfikir dan melakukan inovasi dalam 
pembelajaran. Bentuk respon tersebut adalah mengembangkan disain bahan ajar PAI dengan pendekatan metaforik.

Pendekatan metaforik merupakan kegiatan yang membawa siswa belajar lebih menyenangkan. Sintaks yang ada di dalamnya menantang siswa selalu ingin berlatih berfikir kritis dan mengembangkan kreativitas berfikir. Hal ini disebabkan salah satu elemen penting pendekatan metafora adalah cara belajar dengan bantuan berfikir dan aktivitas beranalogi atau metapora.

Sebab lain yang membuat menarik adalah ternyata istilah analogi adalah disebut juga "qiyas atau amtsal". Istilah amtsal sudah sangat populer dikenal sebagai salah satu cara Allah SWT memahamkan pesan-pesanNya kepada manusia yang terdapat dalam Al-Qur'an. Temuan Wiliam JJ Gordon tentang pendekatan metafora ini adalah pengembangan yang aplikatif dari pesan yang tersirat dalam Al-Qur'an yang sudah sejak lama ada, jauh sebelum penemu pendekatan metafora lahir. Hanya saja masih banyak praktisi pendidikan baik guru atau perancang pembelajaran agama Islam yang belum memanfaatkannya secara maksimal. Melalui kajian ini akan dicoba dan diuji bagaimana bahan ajar pembelajaran PAI yang dirancang dengan metafora ini dapat meningkatkan pemahaman ajaran agama yang abstrak.

Model pembelajaran berbasis pendekatan metafora adalah pembelajaran yang didesain berdasarkan petunjuk Al-Qur'an dengan memanfaatkan langkah-langkah metafora dengan berbantukan media gambar, media benda, cerita sebagai ilustrasi. Karena disain bahan ajar pembelajaran ini berbantukan beragam (multi) perangkat atau media tersebut dapat dituangkan dalam bentuk media yang menarik. Materi bahan ajar yang disesuaikan dengan media ini secara teori akan membantu siswa.

Asumsinya berdasarkan hasil penelitian tentang pemanfaatan multimedia yang dikemukakan Rusman dkk, antara lain: (1) informasi atau materi pelajaran melalui teks dapat diingat lebih baik jika disertai dengan gambar (media) ${ }^{11}$. Hal ini dijelaskan dengan dual coding theory oleh Allan Paivio (1986). Menurut teori ini bahwa sistem kognisi manusia terdiri dari dua subsistem, yaitu sistem verbal, dan sistem gambar (visual) $^{12 ;}$ (2) Menurut Kadek Sukiyasa dkk. berdasarkan hasil analisis penelitiannya, menunjukkan bahwa penyampaian materi sistem kelistrikan otomotif yang menggunakan media animasi (visual) dapat meningkatkan motivasi belajar siswa ${ }^{13}$; (3) Menurut teori "quantum learning" peserta didik memiliki modalitas belajar yang berbeda, yang dibedakan menjadi 3 tipe, yaitu visual, auditif dan kinestetik. Keberagaman modalitas belajar ini diatasi dengan menggunakan perangkat bahan ajar. Sebab masing-masing peserta didik yang berbeda tipe belajarnya dapat diwakili oleh bahan ajar dengan variasi konsep pengembangan di dalamnya.

Kajian ini bertujuan untuk menghasilkan suatu disain pembelajaran baru, yakni pembelajaran PAI dengan pendekatan metafora, yang dirancang untuk memperkuat

\footnotetext{
${ }^{11}$ Rusman, Model-model Multimedia InteraktifBerbasisKomputer, P3MP, UPI, 2005.

${ }^{12}$ Allan Paivio, Mental Representations A Dual Coding Approach, Oxford University Press, New York, Clarendon Press, Oxford, 1990, h. 53.

${ }^{13}$ KadekSukiyasa,

"Pengaruh Media AnimasiterhadapHasilBelajardanMotivasiBelajarSiswaMateriSistemKelistrikanOtomotif”, JurnalPendidikanVokasi, Vol 3, Nomor 1, Februari 2013.
} 
struktur kognitif siswa, sebagai acuan untuk mempelajari model perlakuan yang efektif dalam rangka meningkatkan kemampuan pemahaman konsep abstrak anak didik. Model metafora Gordon sedemikian rupa dimodifikasi dan disesuaikan dengan kondisi yang ada serta diselaraskan dengan kebutuhan pembelajaran Pendidikan Agama Islam, sehingga diperoleh disain pembelajaran PAI dengan metafora yang baru dan dapat mempercepat proses pemahaman siswa.

Oleh karena itu desain baru ini diharapkan akan menumbuhkan pemahaman baru pada materi yang bersifat pemahaman abstrak ${ }^{14}$. Untuk harapan tersebut dibutuhkan pendekatan model dan strategi yang betul-betul dipilih dengan penuh pertimbangan agar proses pembelajaran berlangsung efektif dan efisien. Salah satu pendekatan pembelajaran PAI yang dipandang dapat mencapai tujuan di atas adalah menggunakan model berpikir analogi atau qiyas (amtsal) yang sebenarnya cara ini pernah dicontohkan Nabi Muhammad SAW. dalam pengajaran terhadap muridmuridnya yaitu para sahabat beliau ${ }^{15}$. Cara yang dicontohkan Nabi ini jugalah yaitu analogi atau qiyas ternyata yang menjadi elemen utama pendekatan metafora yang dikenalkan oleh William J.J. Gordon ${ }^{16}$

Asumsi ketepatan penerapan metafora untuk materi abstrak didasarkan pada pernyataan berikut;

Proses metafora dikembangkan dari beberapa asumsi salah satu nya adalah bahwa analisis terhadap proses irasional dan emosional tertentu dapat membantu individu dan kelompok untuk meningkatkan kreativitas mereka dengan menggunakan irasionalitas secara konstruktif. Aspek-aspek irasional dapat dipahami dan dikontrol sacara sadar. Pencapaian kontrol ini melalui penggunaan metafora dan analogi secara seksama, merupakan obyek metafora ${ }^{17}$

Pendapat di atas menguatkan bahwa konsep yang abstrak (aspek keimanan, dan nilai akhlaq) dapat dipahami dengan mudah melalui metafora. Suhudi juga berpendapat bahwa; "analogi atau amtsal dapat digunakan untuk memahamkan sesuatu yang abstrak, sehingga dapat diindra agar mudah diterima, karena makna yang diproses oleh amtsal belum terlintas oleh pikiran kecuali setelah diilustrasikan". Ayat Al-Qur'an surat Al-Baqarah: 264 berikut ini bisa dijadikan dasar;

Hai orang-orang yang beriman, janganlah kamu menghilangkan (pahala) sedekahmu dengan menyebut-nyebutnya dan menyakiti (perasaan si penerima), seperti orang yang menafkahkan hartanya karena riya kepada manusia dan Dia tidak beriman kepada Allah dan hari kemudian. Maka perumpamaan orang itu

\footnotetext{
${ }^{14}$ MateriberupapesanIlahi yang tertuangdalamkitabsuci Al-Qur'an. Lihat H.M. Suyudi, PendidikandalamPerspektif Al-Qur'an, Yogyakarta, Mikraj, 2005, h.70.

${ }^{15}$ IrjusIndrawan, "Model PembelajaranNabi Muhammad SAW; Hiwar, Analogi, TashbihdanAmtsal”, Jurnal al-Afkar, Vol.1 No.2 OktoberTh 2013.

${ }^{16}$ Bruce Jouce, at all, Models Of Teaching, Model-model Pengajaran, Yogyakarta, PustakaPelajar, Cet II, 2011, h. 243. William J. J. Gordon (9 September, 1919 - 30 JUNI 2003) adalahpenemudanpsikolog. Diadiakuisebagaipenciptapendekatanpemecahanmasalah yang disebutSynectics, yang dikembangkansaatbekerja di Invention Design Group of Arthur D. Little. Lihathttps://en.wikipedia.org/wiki/William J. J. Gordon. diunduh 2 Mei 2015.
}

${ }^{17}$ Bruce Joice, Models...., h. 253. 
seperti batu licin yang di atasnya ada tanah, kemudian batu itu ditimpa hujan lebat, lalu menjadilah Dia bersih (tidak bertanah). mereka tidak menguasai sesuatupun dari apa yang mereka usahakan; dan Allah tidak memberi petunjuk kepada orangorang yang kafir ${ }^{18 .}$

\section{${ }^{18}$ QS. Al-Baqarah (2): 264.}

Akmal Hawi, Kompetensi Guru Pendidikan Agama Islam, Jakarta, Rajawali Pers, 2014.

Alfiah,HadisTarbawiy(PendidikanIslamTinjauanHadisNabi),(Pekanbaru:Al-Mujtahadah Press; 2010.

Al- Muchtar,S.EpistemologiPendidikanIlmuPengetahuanSosial.Bandung: Gelar Pustaka Mandiri, 2000.

Arikunto, Suharsini, Prosedur Penelitian Suatu Pendekatan Praktik (Edisi revisi), Jakarta: Rineka Cipta, 1991.

Arikunto, Dasar-Dasar Evaluasi Pendidikan. Jakarta: Bumi Aksara, 2012.

Lorin W. Anderson dan David R. Krathwohl, Ed., Kerangka.

Arifin, Mulyati, Pengembangan Program PengajaranBidang Studi Kimia, Bandung: PT Rosda Karya, 1995.

Aqib, Zainal, Pendidikan Karakter di Sekolah, Membangun Karakter dan Kepribadian Anak, Bandung: Yrama Widya, Cet. 2, 2015.

Badan Pusat Statistik, Indeks Pembangunan Manusia (IPM) 2006 - 2007, Jakarta - Indonesia, Katalog BPS: 4102002.

Dahar, Rina Wilis, Teori-teori Belajar, Jakarta: Erlangga.

Djamarah, Syaiful Bahri, Psikologi Belajar, Jakarta: Rineka Cipta, 2002.

Borg, W.R. \& Gall, M.D, Educational Research, New York: Longman, 1983.

Daradjat, Zakiah, Ilmu Pendidikan Islam, Jakarta: Bumi Aksara, Cet. 9, 2011.

Frye, Mike at all. (Ed.), Character Education: Informational Handbook and Guide for Support and Implementation of the Student Citizent Act of 2001. North Carolina: Public Schools of North Carolina, 2002.

Gulo, Strategi Belajar Mengajar, Jakarta: Grasindo, 2002

Hamalik, Oemar, Kurikulum Dan Pembelajaran, Jakarta: Bumi Aksara, 2011.

Hasbullah,Dasar-DasarImuPendidikan,Jakarta:RajaWaliPress;2005.

Heryanto, "Memahami Karakteristik Peserta Didik SMP dan Implikasinya Terhadap Pembelajaran "http:// rimpu-cili. blogspot. com/ 2012/ 07/ memahamikarakteristik- peserta- didik. html lihat juga http://www.slideshare.net/nhoe_nurjanna/karakteristik-psikomotorik-peserta-didik (diunduh, 21 April 2015).

Hidatulatifah, Ranah-ranah pembelajaran dan Implikasinya dalam Pendidikan Agama Islam, Jurnal Pendidikan Agama Islam, Vol 8, No 1, 2008.

Hilmy, Masdar, Pendidikan Islam dan Tradisi Ilmiyah, Malang Jawa Timur: Madani, 2016.

Hunter, M. The Teaching Process. Dalam The Teachers Handbook. Glenview-Illinois: Scot, Foresman \& Co., 1971.

Ibrahim, Inovasi Pendidikan, Jakarta, Grasindo,1998.

IbnuQayyimAl-Jauziyah,BuabIlmu,Penerjemah FadhliBahri,PustakaAzzam, Jakarta, 1999.

Indrawan, Irjus, "Model Pembelajaran Nabi Muhammad SAW; Hiwar, Analogi, Tashbih dan Amtsal", Jurnal al-Afkar, Vol.1 No.2 Oktober Th 2013

Jalaluddin, Pendidikan Islam, Pendekatan sistem dan Proses, Jakarta, Raja Grafindo Persada, 2016.

Joyce, Bruce dkk, Models of Teaching; Model-model Pengajaran, Yogyakarta: Pustaka Pelajarar, 2012.

Kadar, M. Yusuf, TafsirTarbawi, Yogyakarta: Zanafa; 2001.

KementerianPendidikandanKebudayaan,NaskabPengembangan Akademik Kurikulum, 2011.

Kirschenbaum, 100 Ways to Enhance V alues and Morality in Schools and Youth Settings. Massachusetts: Allyn \& Bacon, 1995.

Koesoema A, Pendidikan Karakter: Strategi Mendidik, Anak di Zaman Global, Jakarta: Grasindo, 2007. 
Perumpamaan yang diungkapkan dalam ayat di atas adalah cara Allah memahamkan kepada hambaNya agar cepat menyerap pesan yang dimaksud di dalamnya. Inilah amtsal sebagai dasar dikembangkanya pendekatan metafora untuk menjelaskan materi-materi agama tentang konsep abstrak. Namun amtsal dalam implementasinya sebagai sarana percepatan proses pembelajaran membutuhkan ilustrasi. Maka sebagai implikasi nya adalah penerapan media tertentu sebagai alat bantu percepatan pemahaman. Media tersebut bisa berupa media benda, media gambar, atau media cerita. Inilah karakter pembelajaran dengan amtsal atau metafora yang bermakna pertalian.

Metafora adalah proses menemukan pertalian dari segala hal yang tidak diketahui sebelumnya atau bahkan bertentangan. Ia meliputi berbagai upaya mengkoordinasikan segala sesuatu ke dalam suatu struktur baru agar ditemukan hubungan antara satu dengan yang lainnya. Dengan kata lain berpikir metafora adalah proses identifikasi segala hal yang tidak diketahui sebelumnya untuk dicari jalan keluarnya, dibuat dugaan-dugaan atau hipotesa.

Dalam tataran praktis dan aplikatif, aktifitas metafora bersifat metaporik dengan menemukan analogi-analogi yang dengan sendirinya kreatifitas menjadi suatu yang disadari. Metapora-metapora membentuk hubungan persamaan serta membedakan obyek atau ide yang satu dengan yang lainnya. Model pembelajaran seperti ini mengajak siswa untuk menjiwai dan menghayati sejumlah konsep-konsep pengetahuan ke dalam ranah afeksi sehingga terjadi proses persepsi dan penghayatan yang mendorong siswa memaknai setiap pengalaman pembelajaran aqidah dan nilai-

Koestoer Partowisastro, Dinamika dalam Psikologi Pendidikan. (Jilid I). Jakarta: Erlangga, 1983.

Lorin W. Anderson dan David R. Krathwohl, Ed., Kerangka

Lampiran Permendikbud No 54Tahun2013 tentang Standar Kompetensi Lulusan Pendidikan Dasar dan Menengah.

Lampiran Permendikbud No. 68 Tahun 2013 tentang Struktur Kurikulum pada Sekolah Menenganh Pertamal Madrasab Stanawiyah.

Marsh, C. \& Stafford, K.., Curriculum Practices, Sydney: Mc Graw-Hill Book Company, 1988.

Marzuki, Pendidikan Karakter Islam, Jakarta: Amzah, 2015.

Ma'arif, Syafi $i$, Pendidikan Islam di Indonesia Antara Cita dan Fakta, Yogyakarta: Tiara, 1991.

Makmun, Abin Syamsudin, Psikologi Kependidikan: Perangkat SistemPengajaran Modul, (Bandung; Remaja Rosda Karya, 2004)

Muhaimin, Paradigma Pendidikan Islam Upaya Mengefektifkan Pendidikan Agama Islam di Sekolah, Bandung: P'T. Remaja Rosdakarya, 2004.

Ngatmanto, Edy dkk., "Effects of Learning Model on Improving the Students' Short Story Appreciation Ability Seen From the Achievement Motivation (Experimental Study in Senior High Schools in Surakarta, Indonesia)" Online International Interdisciplinary Research Journal, \{Bi-Monthly\}, ISSN 2249-9598, Volume-V, Nov 2015.

Partowisastro, Koestoer, Dinamika dalam Psikologi Pendidikan. (Jilid I). Jakarta: Erlangga, 1983.

Paivio, Allan, Mental Representations A Dual Coding Approach, Oxford University Press, New York, Clarendon Press, Oxford, 1990.

Pengembangan Kurikulum; Teori dan Praktek, Bandung, Remaja Rosyda karya, 1977.

QomariAnwar,PendidikanSebagaiKarakterBangsa,Jakarta:UHAMKAPress; 2003.

Q.S. Al Jumu'ah (14): 2.

Ramayulis, Metodologi Pendidikan Agama Islam, Jakarta; Kalam Mulia, 2014. 
nilai akhlaqnya. Selama belajar siswa perlu menguasai konsep kata-kata istilah tertentu. Melalui perbendaharaan dan pemahaman konsep siswa diharapkan tidak sekedar untuk memilikinya, tapi siswa dapat menggunakan konsep miliknya dalam mengorganisasikan dan mengklasifikasikan pengalamannya untuk memecahkan masalah yang dihadapi. Sebab dengan pemahaman konsep didapatkan pengertian atas kata-kata yang dipelajari. Seseorang yang tidak menguasai konsep istilah tertentu akan mengalami kesulitan memahami suatu persoalan materi pengetahuan yang dihadapi. Ini berarti belajar konsep mempunyai arti penting bagi keberhasilan belajar.

Mempelajari kaidah-kaidah diperlukan penguasaan kata-kata istilah, sehingga didapatkan pengertian yang jelas, jauh dari verbaslime yang bersifat hafalan belaka. Kaidah itu sendiri adalah penggabungan dari beberapa konsep yang dihubungkan satu sama lain. Misalnya, dalam menjawab soal-soal uraian diperlukan pemahaman konsep, sehingga tidak terjadi kesalahan kata-kata dalam menjawabnya. Banyak hafalan kata-kata tanpa pemahaman konsep adalah penguasaan bahan yang baku (bahan mentah), jauh dari pengertian.

Pentingnya pemahaman konsep adalah agar siswa dapat menyelesaikan masalah yang relevan dengan konsep tersebut. Untuk memecahkan masalah seorang siswa mesti mengetahui aturan-aturan yang relevan dari konsep-konsep yang diperoleh. Pemahaman konsep aqidah yang notabene bersifat abstrak sebagai hasil belajar akhirnya tercapai. Percepatan terjadi karena tidak perlu menunggu usia lebih dewasa untuk memahami makna konsep aqidah yang benar dan mampu mewarnai sikap prilaku dalam kehidupan sehari-hari.

Demikianlah ahlaq mulia akan terwujud pada diri seseorang karena memiliki aqidah dan syariah yang benar. Seorang Muslim yang memiliki aqidah atau iman yang benar pasti akan terwujud pada sikap dan perilaku sehari-hari yang didasari oleh imannya. Sebagai contoh, orang yang memiliki iman yang benar kepada Allah ia akan selalu mengikuti seluruh perintah Allah dan menjauhi seluruh larangan-larangan-Nya. Dengan demikian, ia akan selalu berbuat yang baik dan menjauhi hal-hal yang dilarang (buruk). Iman kepada yang lain (malaikat, kitab, dan seterusnya) akan menjadikan sikap dan perilakunya terarah dan terkendali, sehingga akan mewujudkan akhlak mulia. Hal yang sama juga terjadi dalam hal pelaksanaan syariah. Semua ketentuan syariat Islam bermuara pada terwujudnya akhlak mulia. Seorang yang melaksanakan shalat yang sesuai dengan ketentuan yang berlaku, misalnya, pastilah akan membawanya untuk selalu berbuat yang benar dan terhindar dari perbuatan keji dan munkar.

\section{Peningkatan Pemahaman Konsep Materi PAI}

Problem sulitnya pembelajaran materi agama aspek Aqidah dan Ahlaq yang bersifat pengetahuan konsep abstrak terhadap peningkatan pemahaman anak adalah; bahan ajar masih berbasis teks dan belum berbasis pada pendekatan pembelajaran aktif tertentu, bahan ajar cetak yang ada belum disusun berdasarkan temuan teknologi pendidikan tertentu yang bisa menyebabkan anak aktif belajar dan lain-lain. Hal tersebut berdampak pada sulitnya pembelajran PAI baik guru sebagai pengajar maupun siswa yang belajar. 
Problem pembelajaran tersebut perlu upaya dalam mengatasinya. Salah satu solusi adalah perlunya penciptaan suasana belajar yang optimal dengan menerapkan pendekatan yang tepat. Dalam pembelajaran Pendidikan Agama Islam, salah satu hal yang perlu diperhatikan oleh guru dalam mengajarkan suatu pokok bahasan adalah pemilihan pendekatan pembelajaran yang sesuai dengan materi yang diajarkan, karena melihat kondisi lemahnya siswa dalam memahami konsep abstrak materi Pendidikan Agama Islam dan penalaran logis siswa.

Menyikapi kenyataan ini, penulis menilai perlu mengembangkan bahan ajar yang sesuai dengan kondisi siswa, yang nantinya dipergunakan dalam proses pembelajaran. Dalam hal ini pengembangan pendekatan dan bahan ajar yang dapat meningkatkan kemampuan pemahaman konsep abstrak materi Pendidikan Agama Islam yaitu bahan ajar Pendidikan Agama Islam berbasis pendekatan Metapora.

Berdasarkan kajian pustaka di atas bahwa bahan ajar Pendidikan Agama Islam aspek Aqidah dan Akhlaq yang digunakan adalah dengan berbasis pendekatan metapora, siswa memperoleh pengetahuannya melalui penalaran yang diberikan oleh guru sehingga menimbulkan daya berimajinasi dan rasa ingin tahu yang memotivasi siswa untuk menyelidiki sendiri masalah yang diberikan oleh guru. Setelah dilakukan stimulasi, langkah selanjutnya adalah guru memberikan kesempatan kepada siswa untuk mengidentifikasi dan menganalisa permasalahan yang mereka hadapi agar terbiasa untuk menemukan suatu masalah guna meningkatkan kemampuan pemahaman konsep abstrak materi Pendidikan Agama Islam. Lalu guru memberikan kesempatan kepada siswa untuk mengumpulkan informasi sebanyak-banyaknya yang relevan antara konsep yang akan difahami dengan langkah-langkah metapora. Ketika data terkumpul, siswa mengolah data dan informasi yang telah diperoleh melalui wawancara, observasi dan sebagainya. Kemudian siswa melakukan proses metapora secara benar dan cermat untuk memperoleh pemahaman konsep baru sebagai indikator peningkatkan kemampuan pemahaman konsep materi agama.

1. Hasil Analisa Draft Produk Pengembangan

Kebutuhan pengembangan bahan ajar berbasis pendekatan metapora adalah berdasarkan analisis kondisi riil pembelajaran PAI yang ada di Sekolah Menengah Pertama. Kondisi riil yang terjadi adalah masih rendahnya pemahaman konsep abstrak ajaran agama, buku bahan ajar belum menggiring siswa untuk belajar lebih kreatif dalam berfikir, bahan ajar PAI yang ada masih berbasis teks.

Berdasarkan analisis diatas maka langkah-langkah dalam penelitian pengembangan telah mengikuti prasyarat dalam penelitian dan pengembangan, yakni (a) tahap studi pendahuluan yang dilakukan dengan menerapkan metode pendekatan deskriptif kualitatif (sebagaimana analisi kebutuhan di atas), (b) tahap pengembangan desain bahan ajar yang kemudian dilanjutkan dengan tahap validasi ahli untuk mengetahui layak atau tidaknya bahan ajar dengan menerapkan pendekatan deskriptif, dan (c) tahap ujicoba, yaitu menerapkan penggunaan bahan ajar kepada siswa dengan metode quasi eksperimen. Sedangkan desain bahan ajar meliputi; (a) mengidentifikasi tujuan pembelajaran, (b) melakukan analisis pembelajaran, (c) mengidentifikasi peserta didik dan 
faktor yang terkait (d) merumuskan tujuan pembelajaran khusus, (e) mengembangkan butir tes, ( $\mathrm{f}$ ) mengembangkan strategi pembelajaran, (g) mengembangkan materi pembelajaran, (8) merancang dan melaksanakan evaluasi formatif dan (9) merevisi bahan pembelajaran.

2. Penyusunan Pengembangan Bahan Ajar

Penyusunan materi PAI sesuai dengan kompetensi dasar, Format pengembangan bahan ajar PAI berbasis pendekatan metafora dan melibatkan pemahaman konsep abstrak siswa. Penyusunan draft awal bahan ajar PAI akan menghasilakan bahan ajar PAI yang didalamnya sekurang-kurangnya mencakup: (a) Judul bahan ajar PAI, (b) Tujuan, (c) Prosedur atau kegiatan siswa (d) Pertanyaan-pertanyaan.

Disain produk pengembangan bahan ajar dengan menggunakan pendekatan metafora untuk mengukur pemahaman berdasarkan sintaks dan disesuaikan dengan RPP. Ada dua strategi dari model pembelajaran metafora, yaitu strategi pembelajaran untuk menciptakan sesuatu yang baru (creating something new) dan strategi pembelajaran untuk melazimkan terhadap sesuatu yang masih asing (making the strange familiar).

Strategi I;

Sintaks Pertama: Mendeskripsikan kondisi saat ini. Guru meminta siswa untuk mendeskripsikan situasi suatu topik yang mereka lihat saat itu.SintaksKedua: Analogi langsung Siswa mengemukakan analogi langsung, salah satu

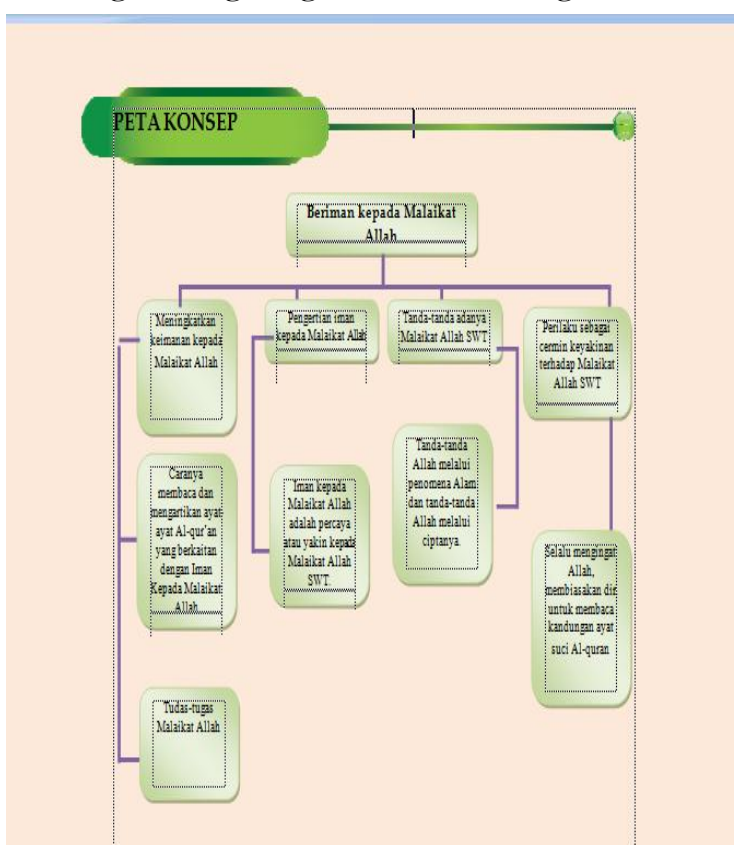
diseleksinya dan selanjutnya dikembangkan.SintaksKetiga: Analogi personal Para siswa menganalogikan sesuatu yang diseleksinya pada fase kedua.SintaksKeempat. Konflik kempaan/ padat. Berdasarkan fase kedua dan ketiga, para siswa mengemukakan beberapa konflik dan dipilih salah satunya.SintaksKelima: Analogi langsung. Para siswa mengembangkan dan menyeleksi analogi langsung lainnya berdasarkan konflik tadi.SintaksKeenam: Meninjau tugas yang sebenarnya Guru meminta para siswa meninjau kembali tugas atau masalah yang sebenarnya dan menggunakan analogi yang terakhir dan atau masuk pada pengalaman metafora.

Strategi II;

SintaksPertama: Input pada keadaan yang sebenarnya. Guru menyajikan informasi dengan topik baru.SintaksKedua: Analogi langsung Guru mengusulkan 
analogi langsung, dan siswa diminta menjabarkannya.Sintaks Ketiga: Analogi personal Guru meminta siswa untuk membuat analogi personal.SintaksKeempat: Membandingkan. Para siswa menjelaskan dan menerangkan kesamaan antara materi yang baru dengan analogi langsung.SintaksKelima: Menjelaskan perbedaan; Para siswa menjelaskan analogi yang tidak tepat.SintaksKeenam: Penjelajahan. Para siswa menjelajahi kembali kebenaran suatu topik dengan batasan-batasan mereka.SintaksKetujuh: Memunculkan Analogi; Para siswa memberikan analogi sendiri secara langsung dan menjelajahi persamaan dan perbedaan.

Demikianlah prosedur penyusunan pengembangan produk ini hingga berbentuk prototype bahan ajar PAI berbasis metafora dengan pokok bahasan Iman kepada Malaikat Allah. Bahan ajar yang tersusun pada tahab pengembangan ini merupakan draft 1 . Berikut adalah contoh pengembangan;
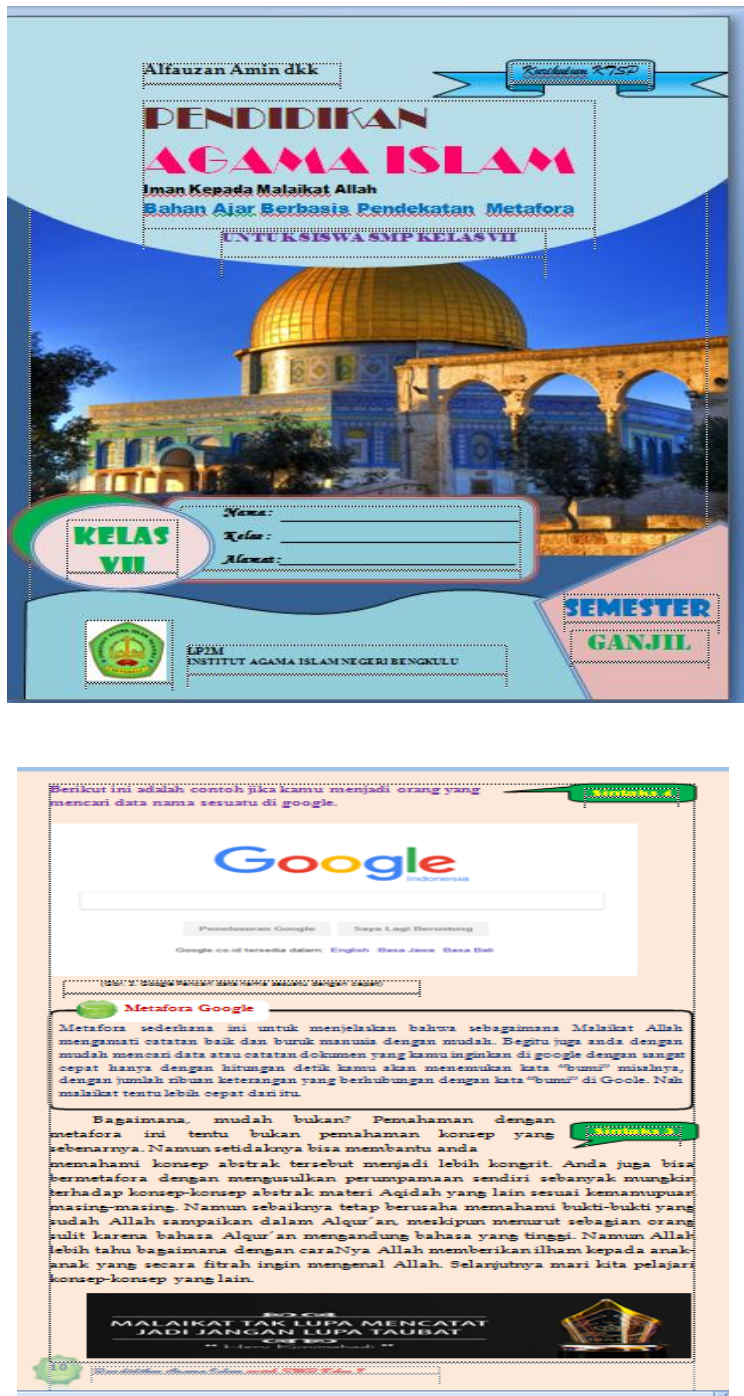

Hasil validasi bahan ajar PAI berbasis metapora bagi siswa SMPN 17 Kota Bengkulu berupa bahan ajar cetak (buku) dengan pendekatanmetaporaoleb abli dan praktisi telah memenuhi komponen kelayakan sebagai bahan ajar yang valid.

Proses kegiatan pembelajaran dengan bahan ajar PAI berbasis metapora bagi siswa SMPN 17 Kota Bengkulu telah memenuhi komponen kelayakan sebagai bahan ajar yang praktis.

Respon siswa dan hasil akhir kegiatan pembelajaran dengan bahan ajar PAI berbasis metapora telah memenuhi komponen kelayakan sebagai bahan ajar yang efektif, untuk meningkatkan pemahaman konssep abstrak siswa sehingga hasil pengembangan dapat direkomendasikan dan dijadikan salah satu alternatif bahan ajar dalam pembelajaran PAI di SMP. Dalam hal ini materi Iman kepada Malaikat Allah (sebagai 
prototipe). Hasil uji lapangan dapat dilihat dari rata-rata perolehan nilai post test pada kelas eksperimen lebih tinggi dibandingkan dengan kelas control. Demikian juga berdasarkan perhitungan pada uji $\mathrm{t}$ test. Setelah dibandingkan dengan $\mathrm{t}$ tabel tingkat kesalahan 5\%, maka dapat disimpulkan bahwa ada perbedaan yang signifikan antara rata-rata kelas eksperimen yang melakukan pembelajaran dengan bahan ajar berbasis metapora dan kelas kontrol yang melakukan pembelajaran dengan bahan ajar yang selama ini digunakan. Dengan demikian, bahan ajar mata pelajaran PAI berbasis pendekatan metapora bagi siswa SMPN 17 Kota Bengkulu memiliki tingkat kelayakan yang baik, hal ini karena bahan ajar metapora ini terbukti telah mampu meningkatkan hasil belajar siswa.

\section{Penutup}

Penelitian dan pengembangan ini telah berhasil memproduk bahan ajar berupa buku pegangan siswa. Bahan ajar tersebut dikembangngkan berdasarkan analisis kebutuhan. Hasl pengembangan berupa draft kemudian diuji validasi, diuji kepraktisan dan keefektifan. Hasil validasi bahan ajar PAI berbasis metapora bagi siswa berupa bahan ajar cetak (buku) dengan pendekatanmetaporaoleh abli dan praktisi telah memenuhi komponen kelayakan sebagai bahan ajar yang valid.Proses kegiatan pembelajaran dengan bahan ajar PAI berbasis metapora bagi siswa telah memenuhi komponen kelayakan sebagai bahan ajar yang praktis.Respon siswa dan hasil akhir kegiatan pembelajaran dengan bahan ajar PAI berbasis metapora telah memenuhi komponen kelayakan sebagai bahan ajar yang efektif,dengan dibuktikan bahan ajar metapora ini terbukti telah mampu meningkatkan hasil belajar siswa.

\section{Daftar Pustaka}

Muhammad Bakar Isma'il, Dirasat fi Ulum Al Qur'an, (Dar Al Manar, Kairo: 1991), h. 337.

Ar Ragib Al Isfahani, Mu'jam Mufradat Alfazh Al Qur'an, (Dar Al Fikr, Beirut: t.t.)., h. 462.

Muhammad Rasyid Ridha, Tafsir Al Manar, Jilid I, (Dar Al Fikr, Beirut: t.t)., h. 236.

Manna Al Qaththan, Mabahits fi Ulum Al Quran, (Mansyurat Al Hasyr Al Hadits, 1973), h. 283.

RosihonAnwar, Ilmu Tafsir, (CV Pustaka Setia, Bandung: 2000), h. 93105.

Muhammad Nasib ar-Rifa'i, Taisiru al-Aliyyul Qadir li Ikbtishari Tafsir Ibn Katsir Jilid 2, (Maktabah Ma'rif Riyadh, Jakarta: 1989), h. 498-500.

Abdul Majid, Perencanaan embelajaran: mengembangkan Standar Kompetensi Guru, (PT Remaj Rosda Karya, Bandung: 2009), h. 144-147. 
Heri Gunawan, Tafsir Tarbawi, (PT Remaja Rosdakarya, Bandung: 2014), h. 64-65.

Rusman, Model-model Multimedia InteraktifBerbasisKomputer, P3MP, UPI, 2005.

Allan Paivio, Mental Representations A Dual Coding Approach, Oxford University Press, New York, Clarendon Press, Oxford, 1990, h. 53.

KadekSukiyasa, "Pengaruh

Media

AnimasiterhadapHasilBelajardanMotivasiBelajarSiswaMateriSistemKelistrikanO tomotif', JurnalPendidikanVokasi, Vol 3, Nomor 1, Februari 2013.

MateriberupapesanIlahi yang tertuangdalamkitabsuci Al-Qur'an. Lihat H.M. Suyudi, PendidikandalamPerspektif Al-Qur'an, Yogyakarta, Mikraj, 2005, h. 70 .

IrjusIndrawan, "Model PembelajaranNabi Muhammad SAW; Hiwar, Analogi, TashbihdanAmtsal”, Jurnal al-Afkear, Vol.1 No.2 Oktober'Th 2013.

Bruce Jouce, at all, Models Of Teaching, Model-model Pengajaran, Yogyakarta, PustakaPelajar, Cet II, 2011, h. 243. William J. J. Gordon (9 September, 1919 30 JUNI 2003) Bruce Joice, Models...., h. 253.

Akmal Hawi, Kompetensi Guru Pendidikan Agama Islam, Jakarta, Rajawali Pers, 2014.

Alfiah,HadisTarbawiy(PendidikanIslamTinjananHadisNabi),(Pekanbaru:Al-

Mujtahadah Press; 2010.

Al-Muchtar,S.EpistemologiPendidikenIlmuPengetahuanSosial.Bandung: Gelar

Pustaka Mandiri, 2000.

Arikunto, Suharsini, Prosedur Penelitian Suatu Pendekatan Praktik (Edisi revisi), Jakarta: Rineka Cipta, 1991.

Arikunto, Dasar-Dasar Evaluasi Pendidikan. Jakarta: Bumi Aksara, 2012.

Lorin W. Anderson dan David R. Krathwohl, Ed., Kerangka.

Arifin, Mulyati, Pengembangan Program PengajaranBidang Studi Kimia, Bandung: PT Rosda Karya, 1995.

Aqib, Zainal, Pendidikan Karakter di Sekolah, Membangun Karakter dan Kepribadian Anak, Bandung: Yrama Widya, Cet. 2, 2015.

Badan Pusat Statistik, Indeks Pembangunan Manusia (IPM) 2006 - 2007, Jakarta - Indonesia, Katalog BPS: 4102002.

Dahar, Rina Wilis, Teori-teori Belajar, Jakarta: Erlangga.

Djamarah, Syaiful Bahri, Psikologi Belajar, Jakarta: Rineka Cipta, 2002.

Borg, W.R. \& Gall, M.D, Educational Research, New York: Longman, 1983.

Daradjat, Zakiah, Ilmu Pendidikan Islam, Jakarta: Bumi Aksara, Cet. 9, 2011.

Frye, Mike at all. (Ed.), Character Education: Informational Handbook and Guide for Support and Implementation of the Student Citizent Act of 2001. North Carolina: Public Schools of North Carolina, 2002.

Gulo, Strategi Belajar Mengajar, Jakarta: Grasindo, 2002

Hamalik, Oemar, Kurikulum Dan Pembelajaran, Jakarta: Bumi Aksara, 2011.

Hasbullah,Dasar-DasarIlmuPendidikan,Jakarta:RajaWaliPress;2005. 
Heryanto, "Memahami Karakteristik Peserta Didik SMP dan Implikasinya Terhadap Pembelajaran'http:// rimpu-cili. blogspot. com/ 2012/ 07/ memahami- karakteristik- peserta- didik. html lihat juga http://www.slideshare.net/nhoe_nurjanna/karakteristikpsikomotorik-peserta-didik (diunduh, 21 April 2015).

Hidatulatifah, Ranah-ranah pembelajaran dan Implikasinya dalam Pendidikan Agama Islam, Jurnal Pendidikan Agama Islam, Vol 8, No 1, 2008.

Hilmy, Masdar, Pendidikan Islam dan Tradisi Ilmiyah, Malang Jawa Timur: Madani, 2016.

Hunter, M. The Teaching Process. Dalam The Teachers Handbook. Glenview-Illinois: Scot, Foresman \& Co., 1971.

Ibrahim, Inovasi Pendidikan, Jakarta, Grasindo,1998.

IbnuQayyimAl-Jauziyah,BuahIlmu,Penerjemah FadhliBahri,PustakaAzzam, Jakarta, 1999.

Indrawan, Irjus, "Model Pembelajaran Nabi Muhammad SAW; Hiwar, Analogi, Tashbih dan Amtsal", Jurnal al-Afkar, Vol.1 No.2 Oktober Th 2013

Jalaluddin, Pendidikan Islam, Pendekatan sistem dan Proses, Jakarta, Raja Grafindo Persada, 2016.

Joyce, Bruce dkk, Models of Teaching; Model-model Pengajaran, Yogyakarta: Pustaka Pelajarar, 2012.

Kadar, M. Yusuf, TafsirTarbawi, Yogyakarta: Zanafa; 2001.

KementerianPendidikandanKebudayaan,NaskahPengembangan Akademik. Kurikulum, 2011.

Kirschenbaum, 100 Ways to Enhance Values and Morality in Schools and Youth Settings. Massachusetts: Allyn \& Bacon, 1995.

Koesoema A, Pendidikan Karakter: Strategi Mendidik Anak di Zaman Global, Jakarta: Grasindo, 2007.

Koestoer Partowisastro, Dinamika dalam Psikologi Pendidikan. (Jilid I). Jakarta: Erlangga, 1983.

Lorin W. Anderson dan David R. Krathwohl, Ed., Kerangka

Lampiran Permendikbud No 54Tahun2013 tentang Standar Kompetensi Lulusan Pendidikan Dasar dan Menengah.

Lampiran Permendikbud No. 68 Tahun 2013 tentang Struktur Kurikulum pada Sekolah Menenganh Pertama/ Madrasah Stanawiyah.

Marsh, C. \& Stafford, K.., Curriculum Practices, Sydney: Mc Graw-Hill Book Company, 1988.

Marzuki, Pendidikan Karakter Islam, Jakarta: Amzah, 2015.

Ma'arif, Syafici, Pendidikan Islam di Indonesia Antara Cita dan Fakta, Yogyakarta: Tiara, 1991.

Makmun, Abin Syamsudin, Psikologi Kependidikan: Perangkat SistemPengajaran Modul, (Bandung; Remaja Rosda Karya, 2004)

Muhaimin, Paradigma Pendidikan Islam Upaya Mengefektifkan Pendidikan Agama Islam di Sekolah, Bandung: PT. Remaja Rosdakarya, 2004. 
Ngatmanto, Edy dkk., "Effects of Learning Model on Improving the Students' Short Story Appreciation Ability Seen From the Achievement Motivation (Experimental Study in Senior High Schools in Surakarta, Indonesia)" Online International Interdisciplinary Research Journal, \{BiMonthly\}, ISSN 2249-9598, Volume-V, Nov 2015.

Partowisastro, Koestoer, Dinamika dalam Psikologi Pendidikan. (Jilid I). Jakarta: Erlangga, 1983.

Paivio, Allan, Mental Representations A Dual Coding Approach, Oxford University Press, New York, Clarendon Press, Oxford, 1990.

Pengembangan Kurikulum; Teori dan Praktek, Bandung, Remaja Rosyda karya, 1977.

QomariAnwar,PendidikanSebagaiKarakterBangsa,Jakarta:UHAMKAPress; 2003. Q.S. Al Jumu'ah (14): 2.

Ramayulis, Metodologi Pendidikan Agama Islam, Jakarta; Kalam Mulia, 2014. 